\title{
Concrete lozenges impact on the slope erodibility
}

\author{
Latifa ELBOUANANI ${ }^{1}$, Khadija BABA ${ }^{1}$, Latifa OUADIF ${ }^{2}$, Abdelaziz LAHMILI $^{2}$ and Lahcen BAHI ${ }^{2}$ \\ ${ }^{1}$ GCE Laboratory, High School of Technology-Sale, Mohammed V University in Rabat-Morocco. \\ 23GIE Laboratory, Mohammadia Engineering School, Mohammed V University in Rabat-Morocco.
}

\begin{abstract}
Water erosion is a natural phenomenon, the severity of which is related to several parameters depending on the raindrop impact, the characteristics of the soil and the level of human intervention. The risk of water erosion occurs in both drainage basins and road and rail slopes. Indeed, this phenomenon can be aggravated causing major gullies and landslides. The PK 94 of the Taourirte-Nador railway line, located in the oriental region of Morocco, whose slopes are formed by silt-clay formations experiencing intense erosion. The Moroccan experience for the slopes protection of water erosion knows the use of several methods in particular; concrete arcades and methods based on biological engineering. The objective is to contribute to this subject by proposing the use of concrete lozenges technique. It have the advantage of reducing both the area at risk of erosion and especially the length of slope which is an important factor in the Revised Universal Soil Loss Equation RUSLE used to quantify the quantities of soil eroded.
\end{abstract}

\section{Introduction}

Nowadays, climate change (a too hot summer and a too rainy winter) and the construction of more and more road, highway and railway networks influenced the slope stability and their resistance to the rainfall and runoff aggressiveness; which gave rise to water erosion.

Water erosion is a natural phenomenon, which is defined as the total process of detachment, transport and deposition of solid particles from the soil surface due to rainfall, runoff or both.

The Rif in general and the Prerif in particular are zones characterized by the predominance of friable lithological formations such as marls, marl-limestone and schist [1].

The drainage basins of the eastern Rif, although less watered, show a much accelerated soil erosion linked to the regime of limited rains in time and space, but which are most often violent and stormy [2]. In the same direction, the slopes surrounding the Taourirte-Nador railway line, more precisely PK 94, due to their location in the oriental Rif, are subject to intense erosion, which necessitates periodic maintenance, generating significant costs.

In Morocco, several approaches were used to map the soil erodibility in different regions in order to estimate erosion and to predict the necessary preventive or curative methods.

In this context, concrete lozenges are a new preventive technique; used in order to protect the slopes subject to water erosion.

The AMERCAIN approach, in particular the Revised Universal Soil Loss Equation RUSLE, is used to quantify the quantities of soil eroded before and after the use of this technique.

\section{Study zone}

\subsection{Situation}

The PK 94 slope of the Taourirte-Nador railway line is located in the North-West of Morocco in the eastern Rif, especially in the city of Nador, which is subject to intense water erosion. 


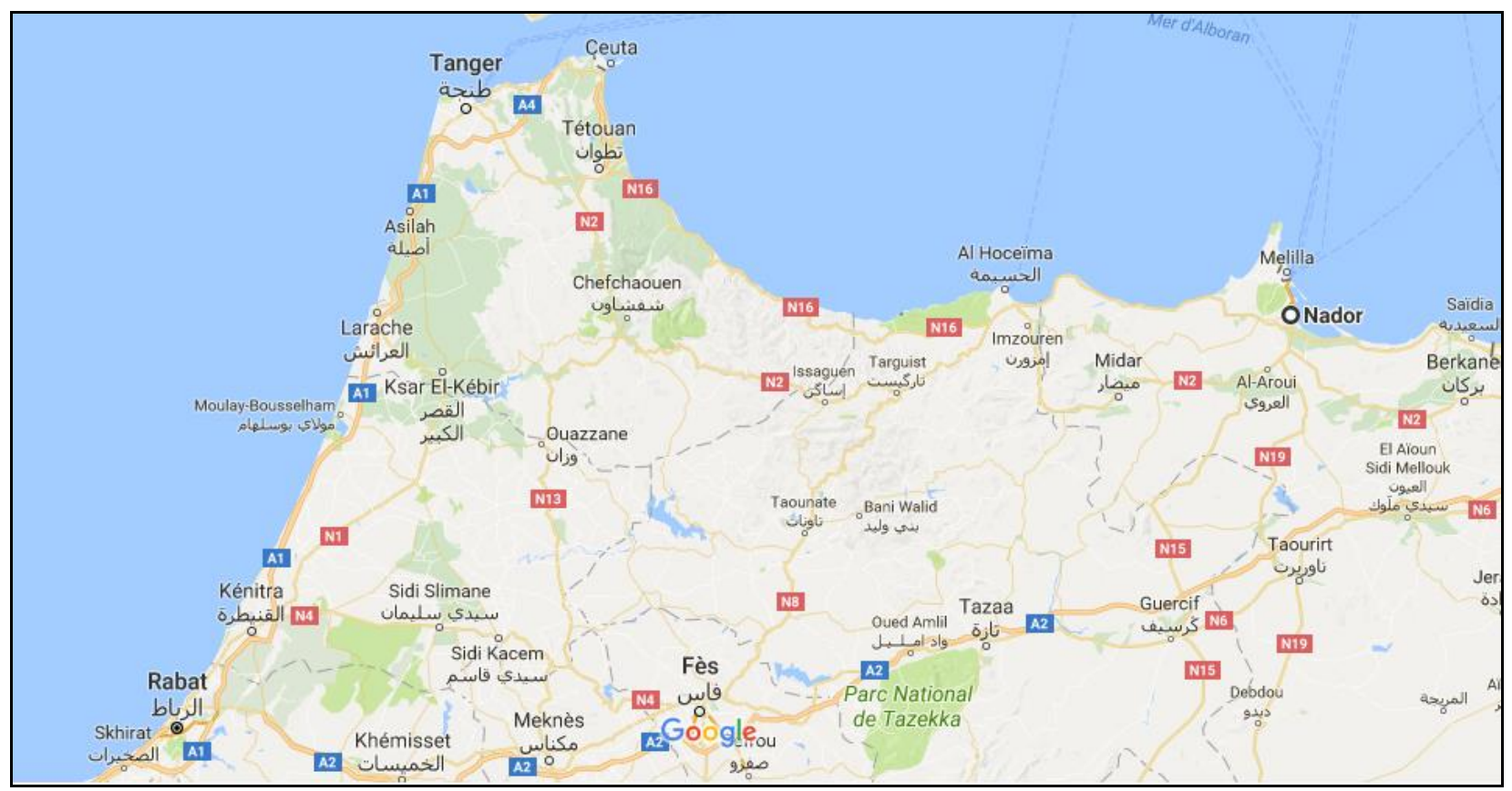

Fig.1.Situation of the PK94 slope of the Taourirte-Nador railway line (Cartographic data (C)2017 Inst. Geogr. Nacional. Monde)

\subsection{Geology}

In the geological context, the oriental Rif presents formations characterized by a superior Miocene, and an inferior Pleistocene belonging to the Villafranchian. These lands consist mainly of pink silts with gravelly beds, and a small band of a powerful quaternary; belonging to the middle quaternary [3].

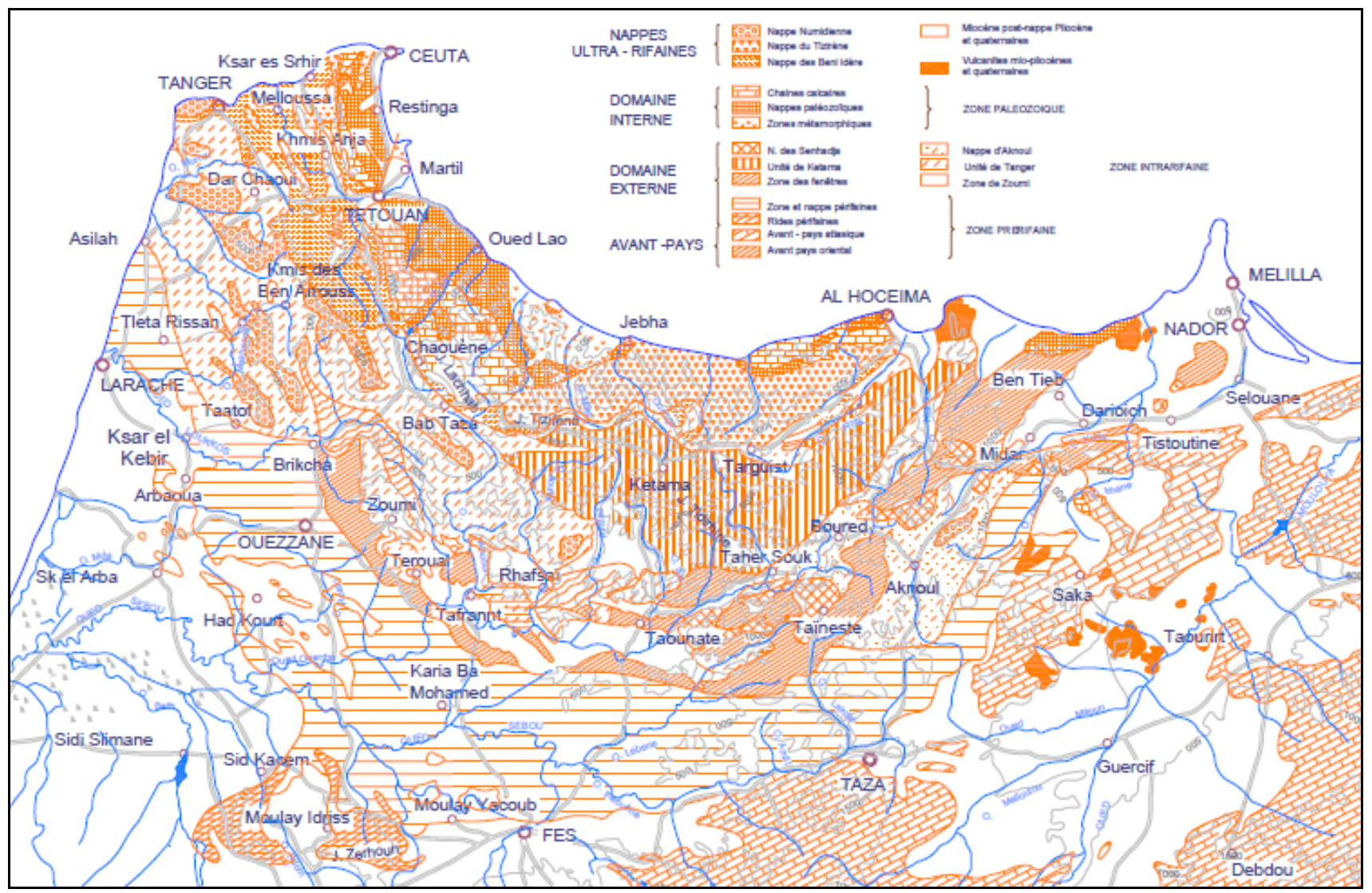

Fig.2.Geology of the study zone (M. Durand Delga \& al, 1961) 


\subsection{Precipitations}

The province of Nador is characterized by a Mediterranean climate, including alternating dry and wet seasons, from June to September, and from October to April. The average annual rainfall is approximately $373,5 \mathrm{~mm} /$ year. The rains are characterized by seasonal variability [3].

The following figure gives the average of total monthly rainfall in mm of 12 years (2001 to 2012)[3]:

\section{Monthly precipitations}

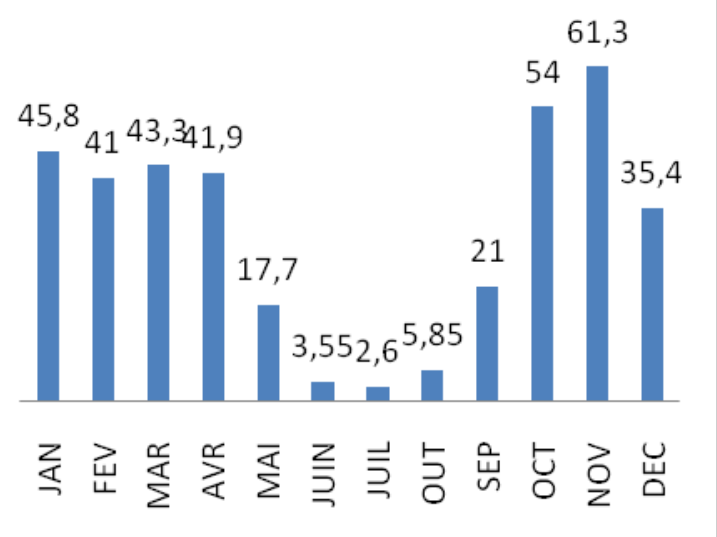

Fig.3.The average of total monthly precipitations in $\mathrm{mm}(2001$ to 2012)

\subsection{Granulometric characteristics}

The soil is characterized by a strong dominance of silt-clay formations and fine sand [3]:

The silt-clay formations have an average of $90 \%$ of particles with a diameter of less than $80 \mu \mathrm{m}$ and $10 \%$ of fine sand.

The fine sand formation comprises an average of $25 \%$ of particles with a diameter of less than $80 \mu \mathrm{m}$.

\section{Methods}

RUSLE is an erosion model designed to predict the long-time average annual soil loss (A) carried by runoff from specific field slopes in specified cropping and management systems as well as from rangeland. It is also applicable to non-agricultural conditions such as construction sites [4].

Soil erosion can be calculated using the Revised Universal Soil Loss Equation such as:

$\mathrm{A}=\mathrm{R} * \mathrm{~K} * \mathrm{LS} * \mathrm{C} * \mathrm{P}$

With:

$\mathrm{A}=$ Predicted soil loss (ton.ha-1.year-1)

$\mathrm{R}=$ Rainfall and runoff factor $(\mathrm{MJ} . \mathrm{mm} /$ ha.h.year $)$;

$\mathrm{K}=$ Soil erodibility factor (t.h/MJ.mm);

$\mathrm{LS}=$ Slope length and steepness factor (a dimensionless factor);

$\mathrm{C}=$ Crop management factor (a dimensionless factor);

$\mathrm{P}=$ Support practices factor (a dimensionless factor).

\subsection{Rainfall and runoff factor ( $R$ )}

The rainfall and runoff factor is the average annual of the sum of the storm EI value; which is the product of total storm energy by the maximum 30-min intensity (I30) (MJ. Mm / ha.h. y).

Given that, we have only the annual and monthly precipitation amounts data, we will use the Rango and Arnoldus equation [5], for the definition of the $\mathrm{R}$ factor.

Therefore, the $\mathrm{R}$ factor can be expressed as follows:

$\log \mathrm{R}=1,74 * \log \Sigma\left(\mathrm{Pi}^{2} / \mathrm{P}\right)+1,29$

With:

Pi: the monthly precipitation in $\mathrm{mm}$;

$\mathrm{P}$ : the annual precipitation in $\mathrm{mm}$.

\subsection{Soil erodibility factor $(\mathrm{K})$}

The soil-erodibility factor $(\mathrm{K})$ is the rate of soil loss caused by the effect of rainfall, runoff and infiltration. It's measured on a plot which has $22.1 \mathrm{~m}$ long, a $1.83 \mathrm{~m}$ minimum width and a $9 \%$ slope.

Soil-erodibility factor can be defined by the soilerodibility nomograph, or by the algebraic approximation used when the silt fraction does not exceed $70 \%$ [4].

Both the graphic and the algebraic method are based on five parameters: \% modified silt, \% modified sand, $\%$ organic matter $(\mathrm{OM})$, classes for structure (s) and permeability (p).

$\mathrm{K}$ can be calculated using the algebraic approximation such us $[4,6]$ :

$\mathrm{K}=\left[2,1.10^{-4}(12-\mathrm{OM}) \mathrm{M} 1.14+3,25(\mathrm{~s}-2)+2,5(\mathrm{p}-3)\right] / 300$

$\mathrm{M}$ is the product of the primary particles size.

$\mathrm{M}=(\%$ modified silt or the $0.002-0.1 \mathrm{~mm}$ size fraction) $\mathrm{x}(\%$ silt $+\%$ sand $)$.

To defining the $\mathrm{s}$ factor, there is a nomographic classification of the soil structure based on the particles size [4]. It is given in the following table:

Table 1: Classification of the soil structure

\begin{tabular}{|c|c|c|}
\hline Class & Type of soil structure & $\begin{array}{c}\text { Size } \\
(\mathbf{m m})\end{array}$ \\
\hline 1 & Very fine granular or without structure & - \\
\hline 2 & Fine granular & $<2$ \\
\hline 3 & Medium granular & $2-5$ \\
& Coarse granular & $5-10$ \\
\hline 4 & Polyhedral, lamellar, massive, prismatic & $>10$ \\
\hline
\end{tabular}

According the soil structure and the soil permeability, Cook \& al(1985) [7] are defined six permeability class. They are presented in the following table: 
Table 2: permeability class

\begin{tabular}{|c|c|c|c|}
\hline $\begin{array}{c}\text { Structural } \\
\text { class }\end{array}$ & $\begin{array}{c}\text { Permeability } \\
\text { class }\end{array}$ & $\begin{array}{c}\text { Permeability } \\
\text { cm/s }\end{array}$ & $\begin{array}{c}\text { Permeability } \\
\text { code }\end{array}$ \\
\hline $\begin{array}{c}\text { Gravel, } \\
\text { coarse sand }\end{array}$ & Fast & $>4,4.10-3$ & 1 \\
\hline $\begin{array}{c}\text { Loam sand } \\
\text { and loams } \\
\text { sandy }\end{array}$ & $\begin{array}{c}\text { Moderate to } \\
\text { Fast }\end{array}$ & $\begin{array}{c}(1,4-4,4) .10- \\
3\end{array}$ & 2 \\
\hline $\begin{array}{c}\text { Fine sand } \\
\text { loams, } \\
\text { loams }\end{array}$ & in moderation & $\begin{array}{c}(0,4-1,4) .10- \\
3\end{array}$ & 3 \\
\hline $\begin{array}{c}\text { Loams, } \\
\text { loam } \\
\text { loams, clay } \\
\text { loams }\end{array}$ & Slow to & $(0,14-$ & 4 \\
\hline $\begin{array}{c}\text { Clay loams, } \\
\text { clays }\end{array}$ & slow & $(4-14) .10-3$ & 5 \\
\hline $\begin{array}{c}\text { Tight, } \\
\text { compacted }\end{array}$ & Very slow & $<4.10-5$ & 6 \\
\hline \multicolumn{2}{|l}{} \\
\hline
\end{tabular}

\subsection{Slope length and steepness factor (LS)}

LS are a dimensionless factor that represents the topography effect on erosion. LS combines both slope length factor ( $\mathrm{L}$ in $\mathrm{m}$ ) and the slope steepness factor ( $\mathrm{S}$ in $\%)$.

\subsubsection{Slope length factor ( $L)$}

Slope length factor can be calculated using the following equation:
Where $\lambda$ is the horizontal projection, 72.6 (ft) is the RUSLE unit plot length and $\mathrm{m}$ is a dimensionless variable slope length exponent $[4,6]$.

$m=\beta /(1+\beta)$

To calculate the slope length exponent (m) we should defining the $\beta$ variable (Foster $\&$ al.1977) $[4,8]$ by the following equation:

$$
\beta=\left(\frac{\sin \theta}{0.0896}\right) /\left(3 *(\sin \theta)^{0.8}+0.56\right)
$$

This value for the ration $\beta$ of rill to interril erosion for conditions when the soil is moderately susceptible to both rill and interill erosion were computed fromthe equation (6). Where $\theta$ is the slope angle.

\subsubsection{Slope steepness factor (S)}

The slope steepness factor $\mathrm{S}$ is defined by the following equation (McCool \& al.1987) [9]:

$$
\begin{array}{ll}
S=10.8 \sin \theta+0.03 & s<9 \% \\
S=16.8 \sin \theta-0.5 & s \geq 9 \%
\end{array}
$$

LS can be defined also using the following table using the slopes angles in $\%$ and the slopes length in $\mathrm{ft}$ :

$\mathrm{L}=(\lambda / 72.6)^{\mathrm{m}}$

\begin{tabular}{|c|c|c|c|c|c|c|c|c|c|c|c|c|c|c|c|c|c|}
\hline \multirow{2}{*}{ Slope \% } & \multicolumn{17}{|c|}{ Slope length in feet } \\
\hline & $<3$ & 6 & 9 & 12 & 15 & 25 & 50 & 75 & 100 & 150 & 200 & 250 & 300 & 400 & 600 & 800 & 1000 \\
\hline 0,20 & 0,05 & 0,05 & 0,05 & 0,05 & 0,05 & 0,05 & 0,05 & 0,05 & 0,05 & 0,05 & 0,06 & 0,06 & 0,06 & 0,06 & 0,06 & 0,06 & 0,06 \\
\hline 0,50 & 0,07 & 0,07 & 0,07 & 0,07 & 0,07 & 0,07 & 0,08 & 0,08 & 0,09 & 0,09 & 0,10 & 0,10 & 0,10 & 0,11 & 0,12 & 12 & 0,13 \\
\hline $1, \mathbf{0 0}$ & 0,09 & 0,09 & 0,09 & 0,09 & 0,09 & $\mathbf{0 , 1 0}$ & 0,13 & 0,14 & 0,15 & 0,17 & 0,18 & 0,19 & $\mathbf{0 , 2 0}$ & 0,22 & 0,24 & 0,26 &, 03 \\
\hline 2,00 & 0,13 & 0,13 & 0,13 & 0,13 & 13 & 0,16 & 0,21 & 0,25 & 0,28 & 0,33 & 0,37 & 0,40 & 0,43 & 0,48 & 0,56 & 0,63 & 0 \\
\hline 3,00 & 0,17 & 0,17 & 0,17 & 0,17 & 0,17 & 0,21 & 0,30 & 0,36 & 0,41 & 0,50 & 0,57 & 0,64 & 0,69 & 0,80 & 0,96 & 1,10 & 1,23 \\
\hline 4,00 & $\mathbf{0 , 2 0}$ & 0,20 & 0,20 & 0,20 & 0,20 & 0,26 & 0,38 & 0,47 & 0,55 & 0,68 & 0,79 & 0,89 & 0,98 & 1,14 & 1,42 & 1,65 & . \\
\hline 5,00 & 0,23 & 0,23 & 0,23 & 0,23 & 0,23 & 0,31 & 0,46 & 0,58 & 0,68 & 0,86 & 1,02 & 1,16 & 1,28 & 1,51 & 1,91 & 2,25 & 2,55 \\
\hline 6,00 & 0,26 & 0,26 & 0,26 & 0,26 & 0,26 & 0,36 & 0,54 & 0,69 & 0,82 & 1,05 & 1,25 & 1,43 & 1,60 & 1,90 & 2,43 & 2,89 & 3,30 \\
\hline 8,00 & 0,32 & 0,32 & 0,32 & 0,32 & 0,32 & 0,45 & 0,70 & 0,91 & 1,10 & 1,43 & 1,72 & 1,99 & 2,24 & 2,70 & 3,52 & 4,24 & 4,91 \\
\hline 10,00 & $\mathbf{0}$ & 0,37 & 0,38 & 0,39 & 0,40 & 0,57 & 0,91 & 1,20 & 1,46 & 1,92 & 2,34 & 2,72 & 3,09 & 3,75 & 4,95 & 03 & 7,02 \\
\hline 12,00 & 0,36 & 0,41 & 0,45 & 0,47 & 0,49 & 0,71 & 1,15 & 1,54 & 1,88 & 2,51 & 3,07 & 3,60 & 4,09 & 5,01 & 6,67 & 8,17 & 9,57 \\
\hline 14,00 & 0,38 & 0,45 & 0,51 & 0,55 & 0,58 & 0,85 & 1,40 & 1,87 & 2,31 & 3,09 & 3,81 & 4,48 & 5,11 & 6,30 & 8,45 & 10,40 & 12,23 \\
\hline 16,00 & 0,39 & 0,49 & 0,56 & 0,62 & 0,67 & 0,98 & 1,64 & 2,21 & 2,73 & 3,68 & 4,56 & 5,37 & 6,15 & 7,60 & 10,26 & 12,69 & 14,96 \\
\hline 20,00 & 0,41 & 0,56 & 0,67 & 0,76 & 0,84 & 1,24 & 2,10 & 2,86 & 3,57 & 4,85 & 6,04 & 7,16 & 8,23 & 10,24 & 13,94 & 17,35 & 20,57 \\
\hline 25,00 & 0,45 & 0,64 & 0,80 & 0,93 & 1,04 & 1,56 & 2,67 & 3,67 & 4,59 & 6,30 & 7,88 & 9,38 & 10,81 & 13,53 & 18,57 & 23,24 & 27,66 \\
\hline 30,00 & 0,48 & 0,72 & 0,91 & 1,08 & 1,24 & 1,86 & 3,22 & 4,44 & 5,58 & 7,70 & 9,67 & 11,55 & 13,35 & 16,77 & 23,14 & 29,07 & 64,71 \\
\hline 40,00 & 0,53 & 0,85 & 1,13 & 1,37 & 1,59 & 2,41 & 4,24 & 5,89 & 7,44 & 10,35 & 13,07 & 15,67 & 18,17 & 22,95 & 31,89 & 40,29 & 48,29 \\
\hline 50,00 & 0,58 & 0,91 & 1,31 & 1,62 & 1,91 & 2,91 & 5,16 & 7,20 & 9,13 & 12,75 & 16,16 & 19,42 & 22,57 & 28,60 & 39,95 & 50,63 & 60,84 \\
\hline 60,00 & 0,63 & 1,07 & 1,47 & 1,84 & 2,19 & 3,36 & 5,97 & 8,37 & 10,63 & 14,89 & 18,92 & 22,78 & 26,51 & 33,67 & 47,18 & 59,93 & 72,15 \\
\hline
\end{tabular}

(4)

Table 3: Slope length and steepness factor (LS) [4] 


\subsection{Crop management factor (C)}

$\mathrm{C}$ is a dimensionless factor that represents the effect of cropping and management practices.

The determination of the $\mathrm{C}$ factor is related to the density of the vegetation cover of the soil surface.

\subsection{Support practices factor (P)}

$\mathrm{P}$ factor, a dimensionless factor, is a ratio that expresses the effect of a specific support practice on the erosion.

The $\mathrm{P}$ factor varies of 0 to 1 as well as the agricultural or anti-erosive practices adopted.

The value 1 corresponds to the ground without antierosion practices.
Table 4: Value of support practices factor (Shin, 1999) [10].

\begin{tabular}{|c|c|}
\hline Slope steepness (\%) & P \\
\hline $0.0-7.0$ & 0.55 \\
\hline $7.0-11.3$ & 0.60 \\
\hline $11.3-17.6$ & 0.80 \\
\hline $17.6-26.8$ & 0.90 \\
\hline$>26.8$ & 1.00 \\
\hline
\end{tabular}

\section{Results and discussion}

The concrete lozenges are inclined concrete drainage channels in the form of lozenges limiting the formation of deep runoff paths increasingly eroding the slope (Figure4).

They have two mains advantages: reducing the area exposed to erosion and collecting and transporting water. In the sense of the RUSLE, this method directly and mainly influences two factors: LS and $\mathrm{P}$ in addition to area exposed to erosion.

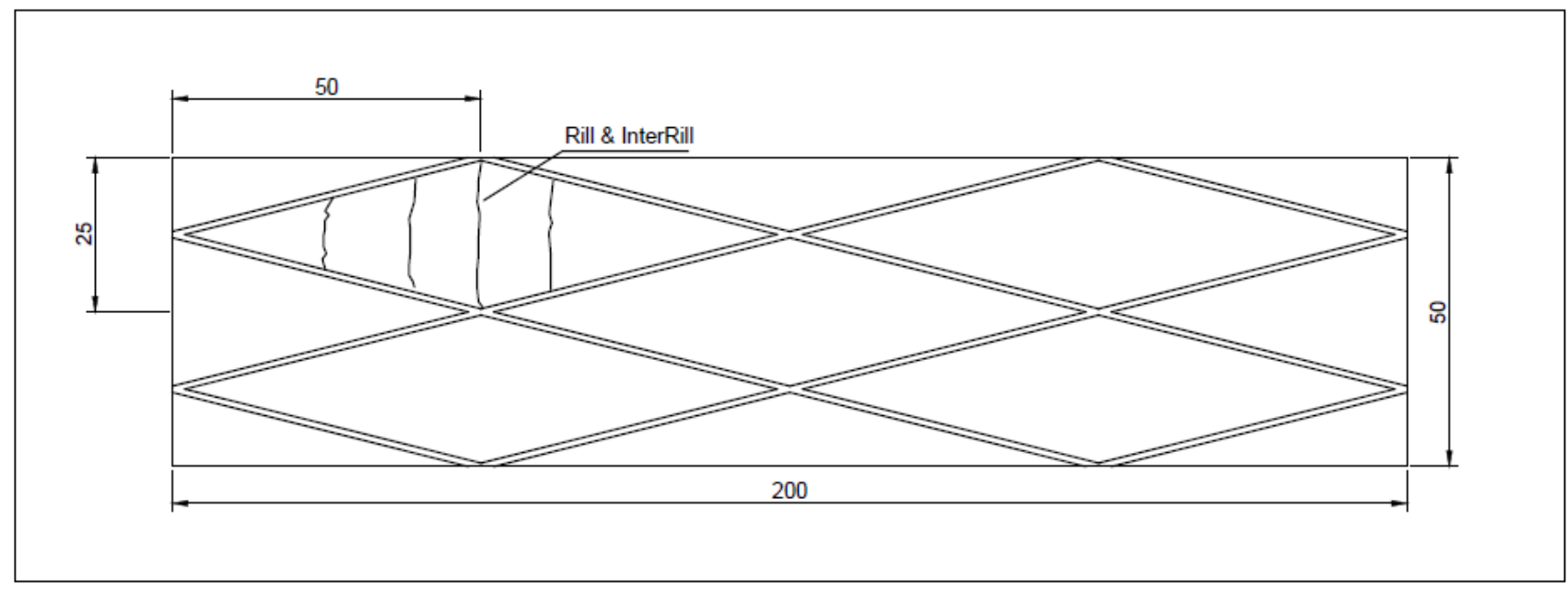

Fig.4.Arrangement of 4 concrete lozenges on an initially unprotected slop

In discussing the concrete lozenges impact on the slope erodibility, we will apply it to the PK 94 slope of the Taourirte-Nador railway line located in the North-West of Morocco in the oriental Rif.

Our study is carried out for a slope area of $50 \times 200=$ $10000 \mathrm{~m} 2=1$ ha.

\subsection{Rainfall and runoff factor $(R)$}

Using the equation (2) R factor has the following value: $\mathrm{R}=150 \mathrm{MJ} . \mathrm{mm} /$ ha.h.year

\subsection{Soil erodibility factor $(K)$}

$\mathrm{K}$ factor is computed according to the equation (3). It has the following value: $\mathrm{K}=0.107 \mathrm{~mm} . \mathrm{t} \cdot \mathrm{ha} / \mathrm{MJ}$.
Table 5: K factor

\begin{tabular}{|c|c|c|}
\hline \% clay & 59 & $\%$ \\
\hline \% Limon & 30 & $\%$ \\
\hline \% fin sand & 10 & $\%$ \\
\hline $\mathrm{M}$ & 1640 & - \\
\hline $\mathrm{OM}$ & 1 & $\%$ \\
\hline $\mathrm{s}$ & 2 & - \\
\hline $\mathrm{p}$ & 3 & - \\
\hline $\mathbf{K}$ & $\mathbf{0 , 1 0 7}$ & $\mathbf{t . h} / \mathbf{M J} . \mathbf{m m}$ \\
\hline
\end{tabular}




\subsection{Slope length and steepness factor (LS)}

The slope steepness is: $3 \mathrm{H} / 1 \mathrm{~V}$

The slope has: $3 \mathrm{H} / 1 \mathrm{~V}, \mathrm{H}=50 \mathrm{~m}$ and $\mathrm{L}=200 \mathrm{~m}$.

So on an area of $50 \times 200=10000 \mathrm{~m}^{2}$; we calculate the quantities of eroded soil with and without concrete lozenges.

For a single lozenge, the runoff length varies from 0 to $\mathrm{Lh}$ with $\mathrm{Lh}=25 \mathrm{~m}$. We therefore take an average value of $\mathrm{Lr}$ equivalent to $\mathrm{Lh} / 2=17,5 \mathrm{~m}$.

The following table presents the results of the LS factor calculation according to the table 3 :

Table 6: LS Factor

\begin{tabular}{|c|c|c|c|}
\hline & $\begin{array}{c}\text { Area } \\
\text { without } \\
\text { lozenges }\end{array}$ & $\begin{array}{c}\text { Area with } \\
4 \\
\text { lozenges }\end{array}$ & \\
\hline $\begin{array}{c}\text { Slope steepness (3H / } \\
\text { 1V) }\end{array}$ & 33 & 33 & $\%$ \\
\hline $\begin{array}{c}\text { The inclination of the } \\
\text { slope }\end{array}$ & 18,45 & 18,45 & $\circ$ \\
\hline Runoff length Lh & 50 & 17,5 & $\mathrm{~m}$ \\
\hline $\begin{array}{c}\text { Horizontal projection of } \\
\text { runoff length }\end{array}$ & 151,02 & 52,86 & $\mathrm{ft}$ \\
\hline LS & $\mathbf{7 , 7}$ & $\mathbf{3 , 2 2}$ & - \\
\hline
\end{tabular}

\subsection{Predicted soil loss A}

The table 7 contains the data required for the Predicted soil loss (A) calculation both before and after the use of concrete lozenges technique.

Table 7: Predicted soil loss (A)

\begin{tabular}{|c|c|c|c|}
\hline & $\begin{array}{c}\text { Area } \\
\text { without } \\
\text { lozenges }\end{array}$ & $\begin{array}{c}\text { Area } \\
\text { with 4 } \\
\text { lozenges }\end{array}$ & \\
\hline Exposed area & 1 & 0,93 & ha \\
\hline LS & 7,7 & 3,22 & - \\
\hline $\begin{array}{c}\text { Erodibility factor } \\
\text { (K) }\end{array}$ & 0,107 & 0,107 & $\begin{array}{c}\mathrm{mm} . \mathrm{t.h} / \\
\text { MJ }\end{array}$ \\
\hline $\begin{array}{c}\text { Erosivity factor } \\
\text { (R) }\end{array}$ & 150 & 150 & $\begin{array}{c}\text { MJ.mm/h } \\
\text { a.h.year }\end{array}$ \\
\hline $\begin{array}{c}\text { The slope is devoid } \\
\text { of vegetation cover } \\
\text { and support } \\
\text { practice (C = 1 and } \\
\text { P = 1) }\end{array}$ & 1 & 1 & - \\
\hline $\begin{array}{c}\text { Predicted soil loss } \\
\text { (A) }\end{array}$ & $\mathbf{1 2 3 , 5 8}$ & $\mathbf{4 8 , 0 6}$ & ton/year \\
\hline
\end{tabular}

\section{Conclusion}

It is concluded that water erosion is a natural risk that can be accentuated or attenuated by human intervention.

Concrete lozenges are a technique to protect the slopes from erosion (by more than $150 \%$ ) and to reduce maintenance interventions, because it allows to:

Reduce the area exposed to the raindrops impact and runoff ( $7 \%$ for 4 lozenges).
Reduce a length factor LS by more than $150 \%$.

Indeed, the number of lozenges required is conditioned by the nature of the soil, the climate conditions, slope length and steepness, crop management and support practices.

A large number of lozenges can have a significant financial impact on the project.

\section{References}

1. Ennadifi Y. Etude géologique du Prérif oriental et son avant-pays (région comprise entre Mezguitem, Ain Zora et Tizroutine). Notes \&Mém.Serv. géol.Maroc, (1974) 253, $66 \mathrm{p}$.

2. Abdelhamid SADIKI, Saïdati BOUHLASSA, Jamal AUAJJAR, Ali FALEH \& Jean-Jacques MACAIRE. Utilisation d'un SIG pour l'évaluation et la cartographie des risques d'érosion par l'Equation universelle des pertes en sol dans le Rif oriental (Maroc) : cas du bassin versant de l'oued Boussouab. Bulletin de l'Institut Scientifique, Rabat, section Sciences de la Terre, 2004, n'26, p. 69-79, (2004).

3. Novec, Tanger Med Ingeneering. Etude d'impact sur l'environnement du nouveau port Nador West Med, mission 01: Etude d'Impact Envionnemental Novec, version définitive -N714-13c, (Juillet 2014).

4. Renard, K.G. G.R. Foster,G.A. Weesies,D.K. McCool,andD.C.Yoder, coordinators. Predicting Soil Erosion by Water: A Guide to Conservation Planning With the Revised Universal Soil Loss Equation (RUSLE).USDA; United State Department of Agriculture, Agricultural Research Service agriculture handbook number 703, 404pp, (1997).

5. Rango A. \&Arnoldus H.M.J. Aménagement des bassins versants. Cahiers techniques de la FAO, (1987).

6. Wischmeier, W.H. \& Smith D.D. Prediction rainfall erosion losses, a guide to conservation planning Science .U.S. Dept. Agriculture. Agric. Handbook 537, 60p, (1978).

7. A.CHEHLAFI, A.KCHIKACH, A. DERRADJI; Protection des talus autoroutiers par arcades bétonnées ou maçonnées. Rock Slope Stability, Marakech - Maroc, 2 au 4 Avril (2014).

8. Foster,G.R, L.D.Meyer and C.A.Onstad. A runoff erosivity factor and variable slope length exponents for soil loss estimates. Trans. ASAE 20:683-687, (1977).

9. McCool, D.K, L.C.Brown, G.R.Foster, et al. Revised slope steepness factor for the Universal Soil Loss Equation.Trans.ASAE 30:1387.1396 (1987).

10. Shin, G. J. The analysis of soil erosion analysis in watershed using GIS, Ph.D. Dissertation, Department of Civil Engineering, Gang-won National University, (1999). 